\title{
Article \\ Deformation Behavior of Hard Roofs in Solid Backfill Coal Mining Using Physical Models
}

\author{
Nan Zhou ${ }^{1,2}$, Jixiong Zhang ${ }^{1,2}$, Hao Yan ${ }^{1,2, *}$ and Meng Li ${ }^{1,2}$ \\ 1 State Key Laboratory of Coal Resources and Safe Mining, China University of Mining \& Technology, \\ Xuzhou 221116, China; zhounanyou@126.com (N.Z.); zjxiong@163.com (J.Z.); limeng77521@126.com (M.L.) \\ 2 Key Laboratory of Deep Coal Resource Mining, Ministry of Education of China, \\ China University of Mining \& Technology, Xuzhou 221116, China \\ * Correspondence: cumtyhao@163.com; Tel: +86-138-1347-2587
}

Academic Editor: Moran Wang

Received: 13 March 2017; Accepted: 12 April 2017; Published: 18 April 2017

\begin{abstract}
Solid backfill coal mining technology has been widely applied in coal seams that are at risk of hard roof. Using actual measured strain-stress curves of the backfill body and the similarity theory, this study designed and employed four experimental models for physical simulation, corresponding to roof-controlled backfilling ratios of $0 \%, 40 \%, 82.5 \%$ and $97 \%$ using the geological conditions of Face No. 6304 in the Jining No. 3 coal mine-a solid backfill coal mining face under a hard roof. A non-contact strain measurement system and pressure sensors were used to monitor the deformation of the overlying strata and changes in abutment stress ahead of the face during mining of the models for varying roof-controlled backfilling ratios. The results indicated that the solid backfill body was able to support the roof. As the roof-controlled backfilling ratio was increased, the maximum subsidence of the roof and the maximum height of the cracks decreased. When the roof-controlled backfilling ratio was $82.5 \%$ or higher, the working face did not display any obvious initial fractures or periodic fractures, and both the value and the impact range of the abutment stress ahead of the face decreased.
\end{abstract}

Keywords: hard roofs; solid backfill coal mining; physical models; rockburst; roof-controlled backfilling ratio

\section{Introduction}

A hard roof [1-3] refers to the thick strata above a coal seam or above a thin immediate roof. Such a roof generally has high strength and low caving immediately after each mining operation. With the continuing advance of the longwall face and the increase of the overhang area, the stress in the hard roof eventually exceeds its ultimate strength and the roof caves suddenly, which causes a rapid release of the energy stored in the roof and the coal seam. This often results in coal mine catastrophic dynamic events, such as wind blasting, causing serious damage to mining equipment, significant mining delays, and sometimes casualties [4-7]. The hard roof is one of the main causes of a coal mine burst at the longwall face [8,9]. It is of great importance to note that in China, coal reserves under hard roofs account for about one-third of total reserves; moreover, nearly $40 \%$ of fully mechanized coal mining panels have hard roofs, and more than $50 \%$ of mining areas suffer from problems associated with hard roofs $[10,11]$.

In recent years, backfill coal mining [12,13] has become a popular and widely applied mining method for the safe extraction of coal resources trapped under buildings, railways, and water bodies. This technique fills the goaf area with solid waste, such as gangue, to effectively control the movement of both the roof and the overlying strata. Numerous case studies [14-16] have demonstrated that backfill coal mining can effectively control the movement of both the roof and the overlying strata. 
In comparison with the traditional longwall caving method, backfill coal mining can greatly reduce the abutment stress around the excavation surface. For these reasons, Zhou and Zhang $[17,18]$ proposed a solid backfill method for controlling hard-roof-induced dynamic disasters; their method has been verified both in theory and in practice.

However, different backfill systems have different abilities to control the deformation of the hard roof and different pressure profiles in the working face. Based on the geological conditions of the 6304-1 working face in the Jisan coal mine, this paper compares the deformation of the hard roof in the working face for four backfill scenarios using physical simulation models (Compared with numerical modelling, physical modelling results are more reliable because numerical modelling has difficulties in parameter selection). The results can provide basic data to inform the design of backfill parameters, the selection of appropriate backfill support, and roadway support.

\section{Design of Physical Simulation Models}

\subsection{Principle of Solid Backfilling}

The backfilling system was developed to handle solid backfill materials as an integral part of the original fully mechanized coal mining system $[19,20]$. Backfill coal mining technology consists of five main production systems. Its coal transport system, auxiliary transport system, and ventilation system are the same as those used in traditional fully mechanized coal mining. The two additional systems that backfill coal mining employs are a solid waste transport system and a backfill system. The solid waste transport system transports the solid waste from the surface to the underground working face. The backfill system places the dense backfill material in the gob area.

The backfill hydraulic supports [21,22] are key to the success of solid backfilling. As shown in Figure 1, its front canopy supports the roof, providing a safe space to operate mining machines, and its back canopy offers the space required to transport the backfill material, and to dump and compact it in the gob. The backfilling scraper conveyor, used for transporting the solid backfill materials, is hung below the rear roof canopy. Another important piece of equipment in the rear part of the backfill hydraulic support is the tamping arm, which can provide a pressure of $2 \mathrm{MPa}$ to push the backfill materials into the gob and compact them to a sufficient density to effectively support the roof [11].

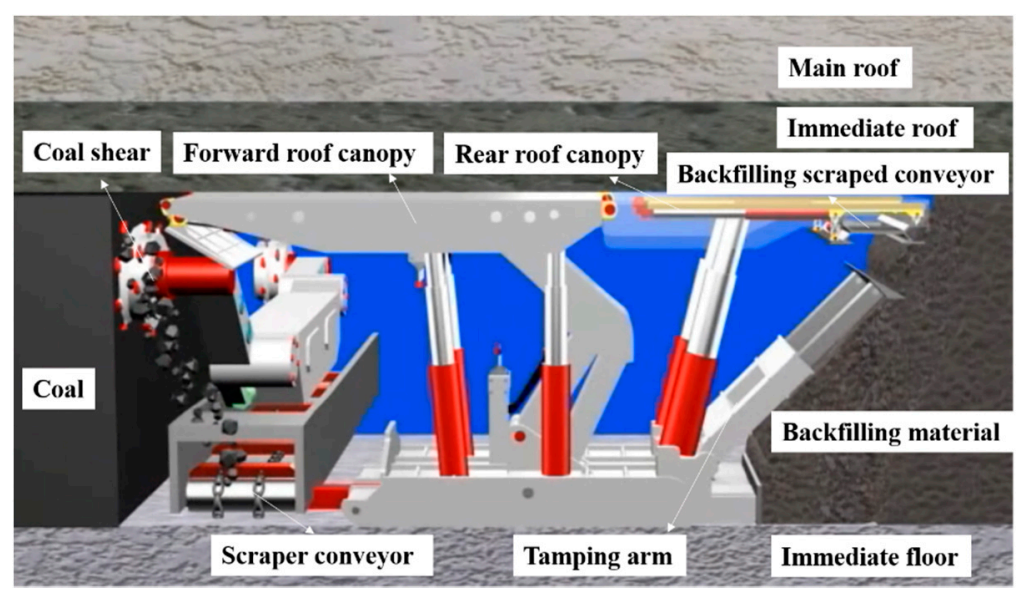

Figure 1. Backfilling hydraulic support at the working face.

\subsection{Basic Parameters of the Working Face}

Backfill coal mining technology has been applied in Panel No. 6304-1 of the Jisan coal mine, where the No. 3 coal seam of the Shanxi formation is the main mineable coal seam. The average thickness of the No. 3 coal seam is $3.5 \mathrm{~m}$, its average dip is $2.5^{\circ}$, its density is $1.36 \mathrm{t} / \mathrm{m}^{3}$, and its average depth is $650 \mathrm{~m}$. It has no immediate roof. The main roof is a fine sandstone of $32.5-49.75 \mathrm{~m}$ 
thick (with an average thickness of $41.6 \mathrm{~m}$ ), the uniaxial compressive strength is $84.4 \mathrm{MPa}$, the tensile strength is $13.5 \mathrm{MPa}$, and the elastic modulus is $17.0 \mathrm{GPa}$. It can be regarded as a hard roof. The panel, No. 6304, was divided into three working faces, with a face length of $80 \mathrm{~m}$ and advancing distance of $518 \mathrm{~m}$. The physical simulation experiment was mainly based on the specific conditions of Panel No. 6304-1, whose working face layout is shown in Figure 2.

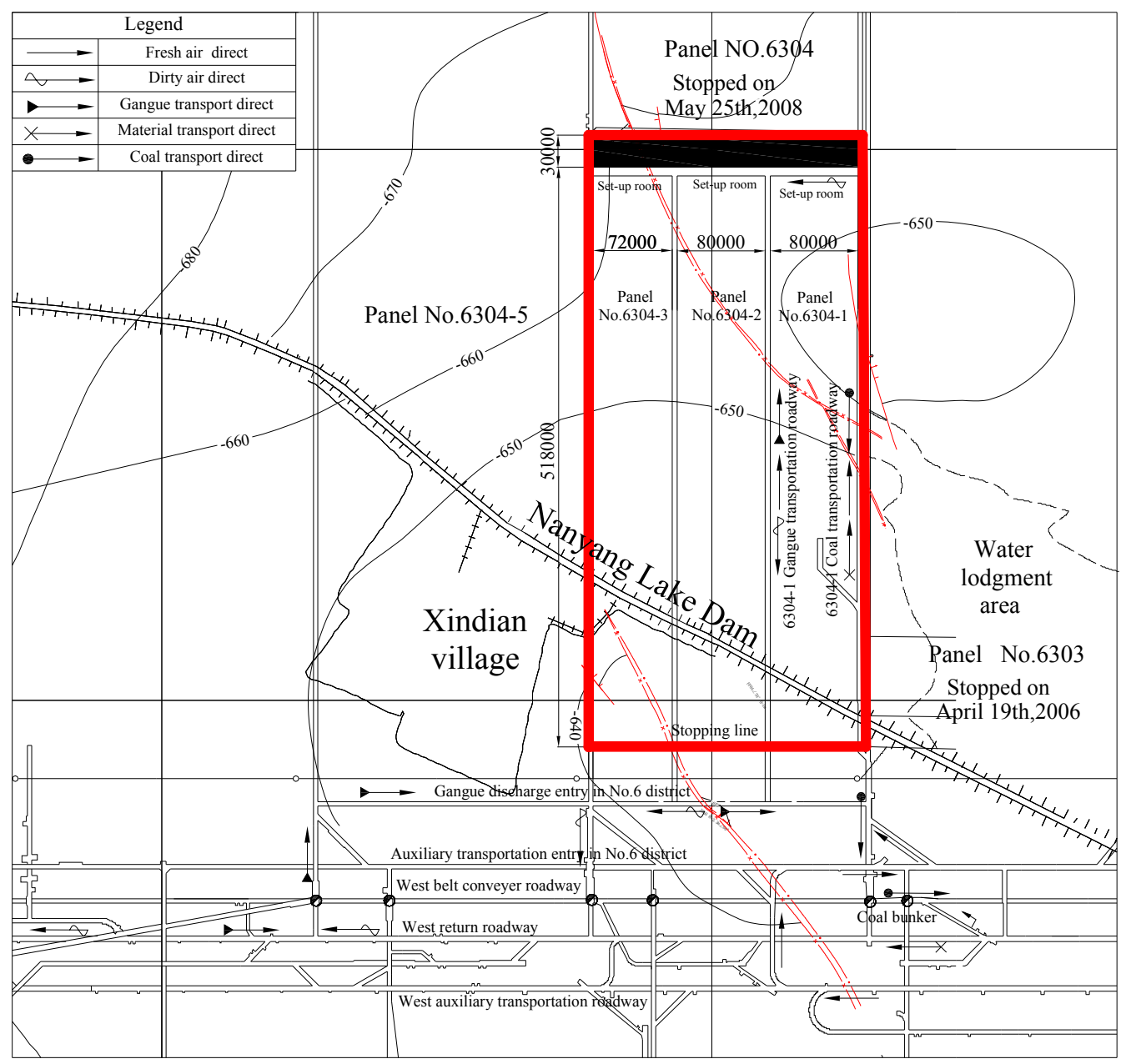

Figure 2. Mine layout around Panel No. 6304-1.

\subsection{Experimental Installation and Determination of Model Simulation Scale}

\subsubsection{Experimental Installation}

Model supports measuring $2.30 \mathrm{~m} \times 0.30 \mathrm{~m} \times 1.80 \mathrm{~m}$ were used to perform the experiments, with pressure water bags used as the compensatory loads. Changes in the abutment stress ahead of the working face were monitored using pressure sensors arranged inside the coal seam and a TS3890 static strain indicator (Yangzhou Thai Electronics Co., Ltd., Yangzhou, China). A non-contact strain measurement system was used to monitor displacement variations in the overlying strata. The system used an advanced 2D digital image correlation algorithm, which can measure arbitrary displacement and deformation from 500 micro strain to more than five times strain. The size of the observed model is from $1 \mathrm{~mm}$ to $10 \mathrm{~m}$. This monitoring system uses an industrial digital camera (29 million pixels), optical lens, lighting, matching notebook, Flycapture software, and Vic-2D (Beijing Deanwell Technology Co., Ltd., Beijing, China). The Flycapture software relies on the Canadian PointGrey industrial digital camera. Vic-2D can realize the data-output constantly and deal with the data. The arrangement of the measurement and data processing systems is shown in Figure 3. 


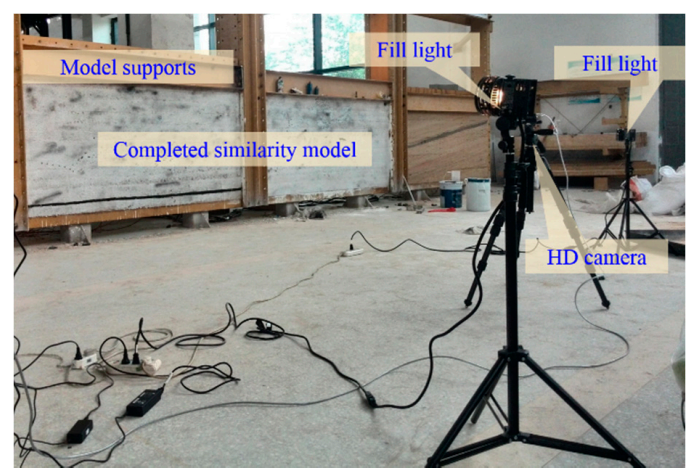

(a)

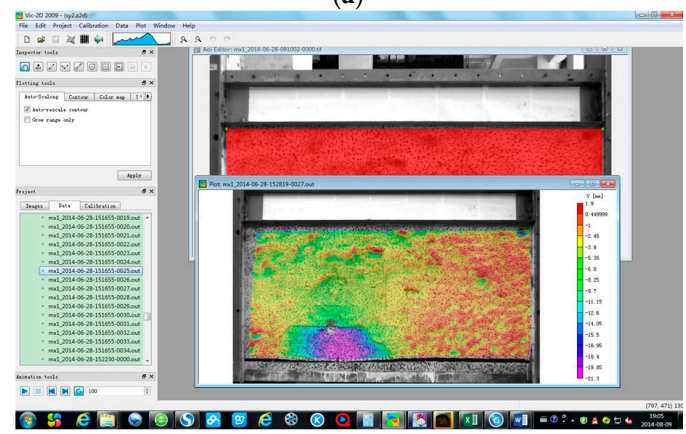

(b)

Figure 3. Non-contact strain measurement system. (a) Monitoring equipment and its placement; (b) Data processing system.

\subsubsection{Determination of the Model Simulation Scale}

Based on similarity criteria including geometrical conditions, ambient conditions, boundary conditions, and initial conditions, and considering the geological conditions of the actual working face and the size of the model supports, the geometric similarity ratio $C_{l}$ of the model was determined to be 150:1. As the volume-weight of actual rocks is about $25 \mathrm{kN} / \mathrm{m}^{3}$, and the materials used to establish the model have an average volume-weight of $15 \mathrm{kN} / \mathrm{m}^{3}$, the volume-weight similarity ratio of the model was determined to be 1.667:1. Calculations indicated that $C_{t}=\sqrt{C_{l}}=12.25: 1$, and that the stress similarity ratio $C_{p}=C_{r} C_{l}=250: 1$.

\subsection{Design of Model Parameters}

Each model was designed to consist of nine strata including the coal seam, hard roof, immediate roof, and partially overlying strata. The model size was $2.30 \mathrm{~m} \times 0.30 \mathrm{~m} \times 1.23 \mathrm{~m}$ $(\mathrm{L} \times \mathrm{W} \times \mathrm{H})$. The real height on site was $184.80 \mathrm{~m}$. The rock strata that were not laid were approximately $475 \mathrm{~m}$ thick. According to the stress similarity ratio, a compensatory load of $0.0475 \mathrm{MPa}$ was required, which was applied using pressure water bags.

The height, strength, and material mixing proportion for each rock stratum in the models were calculated based on the site test results of the actual lithology and the principle of similarity. They are shown in Table 1.

The rock masses in the models were laid from bottom to top. Before the placement of each stratum, sand, calcium carbonate, plaster, and water were mixed in a blender with the mass of each component as shown in Table 2. After mixing, the materials were spread evenly and smoothly on the model support and tamped by a special hammer to create the appropriate stratum height. Next, a layer of mica plate with a thickness not more than $1 \mathrm{~mm}$ was laid evenly over the stratum before the placement of the next stratum. Once completed, the surface of the model was monitored by the speckle, as shown in Figure 4. The model is laid on the model support which can provide boundary constraints, and the model can simulate the movement and deformation of the coal seam, hard roof, and overlying strata. 
Table 1. Thickness and mechanical parameters of coal and rock mass.

\begin{tabular}{|c|c|c|c|c|c|c|c|c|c|}
\hline \multirow{2}{*}{$\begin{array}{l}\text { Stratum } \\
\text { Number }\end{array}$} & \multirow[b]{2}{*}{ Lithology } & \multicolumn{2}{|c|}{ Height } & \multicolumn{2}{|c|}{ Compressive Strength } & \multicolumn{4}{|c|}{ Material Mixture Ratio (kg) } \\
\hline & & $\begin{array}{l}\text { Actual } \\
\text { (m) }\end{array}$ & $\begin{array}{c}\text { Model } \\
(\mathrm{mm})\end{array}$ & $\begin{array}{l}\text { Actual } \\
\text { (MPa) }\end{array}$ & $\begin{array}{l}\text { Model } \\
(\mathbf{k P a})\end{array}$ & Sand & $\begin{array}{l}\text { Calcium } \\
\text { Carbonate }\end{array}$ & Gypsum & Water \\
\hline 1 & Fine sandstone & 14.27 & 95 & 56.16 & 224.60 & 94.52 & 7.09 & 16.54 & 14.77 \\
\hline 2 & Mudstone & 24.14 & 161 & 23.53 & 94.10 & 159.90 & 27.98 & 11.99 & 24.98 \\
\hline 3 & Fine sandstone & 19.45 & 130 & 51.96 & 207.80 & 120.78 & 20.13 & 20.13 & 20.13 \\
\hline 4 & Silty sandstone & 24.20 & 161 & 37.92 & 151.65 & 160.30 & 20.04 & 20.04 & 25.05 \\
\hline 5 & Mudstone & 27.75 & 185 & 25.29 & 101.14 & 201.05 & 14.36 & 14.36 & 28.72 \\
\hline 6 & $\begin{array}{l}\text { Sandstone and } \\
\text { mudstone } \\
\text { interbedding }\end{array}$ & 21.85 & 146 & 28.43 & 113.70 & 135.69 & 31.66 & 13.57 & 22.61 \\
\hline 7 & $\begin{array}{l}\text { Fine sandstone } \\
\text { (hard roof) }\end{array}$ & 41.63 & 277 & 70.0 & 279.9 & 258.52 & 25.85 & 60.32 & 43.09 \\
\hline 8 & Coal & 3.50 & 24 & 11.2 & 44.78 & 26.08 & 2.61 & 1.12 & 3.73 \\
\hline \multirow[t]{2}{*}{9} & Silty sandstone & 8.00 & 54 & 40.20 & 160.77 & 79.49 & 9.94 & 9.94 & 12.42 \\
\hline & Total & 184.79 & 1233 & - & - & 1236.33 & 159.66 & 168.01 & 195.5 \\
\hline
\end{tabular}

Table 2. Backfill mining status of each simulation program.

\begin{tabular}{cccc}
\hline Group & $\begin{array}{c}\text { Roof-Controlled } \\
\text { Backfilling Ratio }\end{array}$ & Actual Mining and Backfill State & Model Mining and Backfill State \\
\hline 1 & 0 & Caving mining. & The height of mining is $24 \mathrm{~mm}$, no backfill. \\
\hline 2 & $40 \%$ & $\begin{array}{c}\text { The height of mining is } 3500 \mathrm{~mm}, \\
\text { the height of backfill is } 1800 \mathrm{~mm}, \\
\text { no compaction. }\end{array}$ & $\begin{array}{c}\text { The height of mining is } 24 \mathrm{~mm} \text {, the height } \\
\text { of backfill is } 12 \mathrm{~mm} \text {, initial loading stress of } \\
\text { backfill body is } 0 \mathrm{MPa} \text {. }\end{array}$ \\
\hline 3 & $82.5 \%$ & $\begin{array}{c}\text { The height of mining is } 3500 \mathrm{~mm}, \\
\text { the height of backfill is } 3600 \mathrm{~mm}, \\
\text { no compaction. }\end{array}$ & $\begin{array}{c}\text { The height of mining is } 24 \mathrm{~mm} \text {, the height } \\
\text { of backfill is } 24 \mathrm{~mm} \text {, initial loading stress of } \\
\text { backfill body is } 0 \mathrm{MPa} \text {. }\end{array}$ \\
\hline 4 & $\begin{array}{c}\text { The height of mining is } 3500 \mathrm{~mm}, \\
\text { the height of backfill is } 3600 \mathrm{~mm}, \\
\text { compaction strength is } 2 \mathrm{MPa} .\end{array}$ & $\begin{array}{c}\text { The height of mining is } 24 \mathrm{~mm} \text {, the height } \\
\text { of backfill is } 24 \text { mm, initial loading stress of } \\
\text { backfill body is } 8 \mathrm{kPa} \text {. }\end{array}$ \\
\hline
\end{tabular}

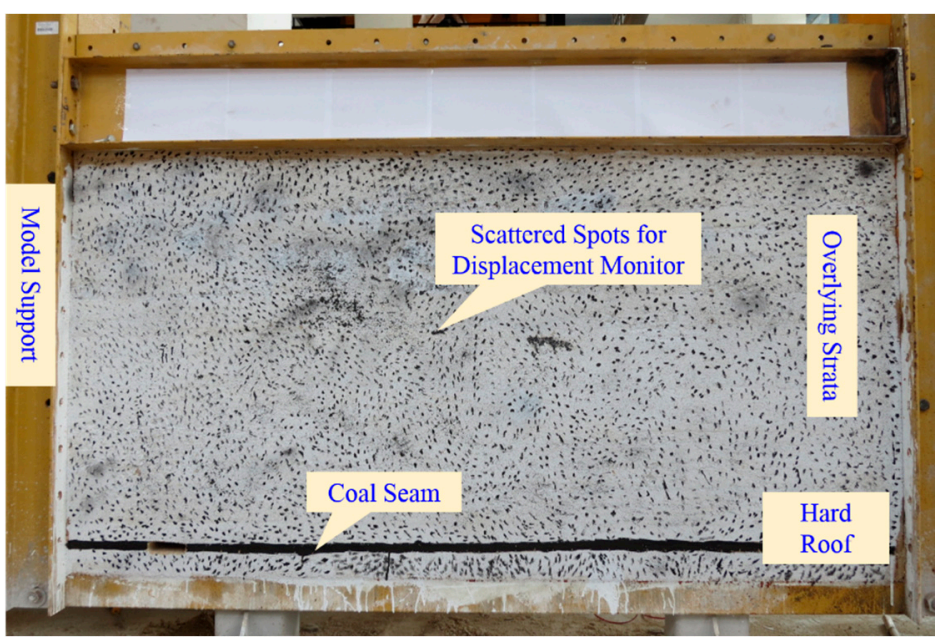

Figure 4. Completed model.

\subsection{Backfill Mining of the Models and Design of Monitoring Scheme}

\subsubsection{Design of Scenarios for Comparison}

Four groups of physical simulation experiments with different backfilling states were performed. The mining and backfilling states of each group are shown in Table 2. 
For convenience of description, the term "roof-controlled backfilling ratio" was devised to describe the backfilling effects $[23,24]$. It refers to the ratio of the backfill body height to the mining height under the condition that the stress to which the backfill body is subjected is due to the weight of the main roof and the overlying soft strata. This index directly reflects the control effects of a backfill body on the roof. Specific to Face No. 6304-1, the gravity sum of the hard roof and the weak strata that deform with the hard roof was $2.27 \mathrm{MPa}$ and the roof-controlled backfilling ratio in this case was referred to as the ratio of the backfill body height and the mining height when the stress endured by the backfill body was $2.27 \mathrm{MPa}$.

\subsubsection{Backfill Mining and Monitoring of the Models}

Mining commenced once the models had been laid and dried for a period of 10 days. On the actual site, each shift lasted $8 \mathrm{~h}$. In each 24-hour period there were two shifts for mining and one shift for maintenance, and a footage of about $3600 \mathrm{~mm}$ was achieved. Based on the advance rate of two days, a cycle of mining $(50 \mathrm{~mm})$ and backfilling $(50 \mathrm{~mm})$ of the model every $200 \mathrm{~min}$ was established, until the stop line of the face was reached. To eliminate the boundary effect, both the start line and the stop line were $250 \mathrm{~mm}$ from the boundary. The mining distance was $1800 \mathrm{~mm}$, for which 36 cycles of mining were required.

The non-contact strain measurement system collected the displacement data of the model every $2 \mathrm{~s}$ - to monitor the displacement of each rock stratum, before and after each cycle of mining and backfilling. Six pressure sensors were arranged in the coal seam to assist the strain measurement system and to monitor the changes of abutment stress ahead of the face during the mining process. The model mining and backfilling sequence and the distribution of pressure sensors are shown in Figure 5.

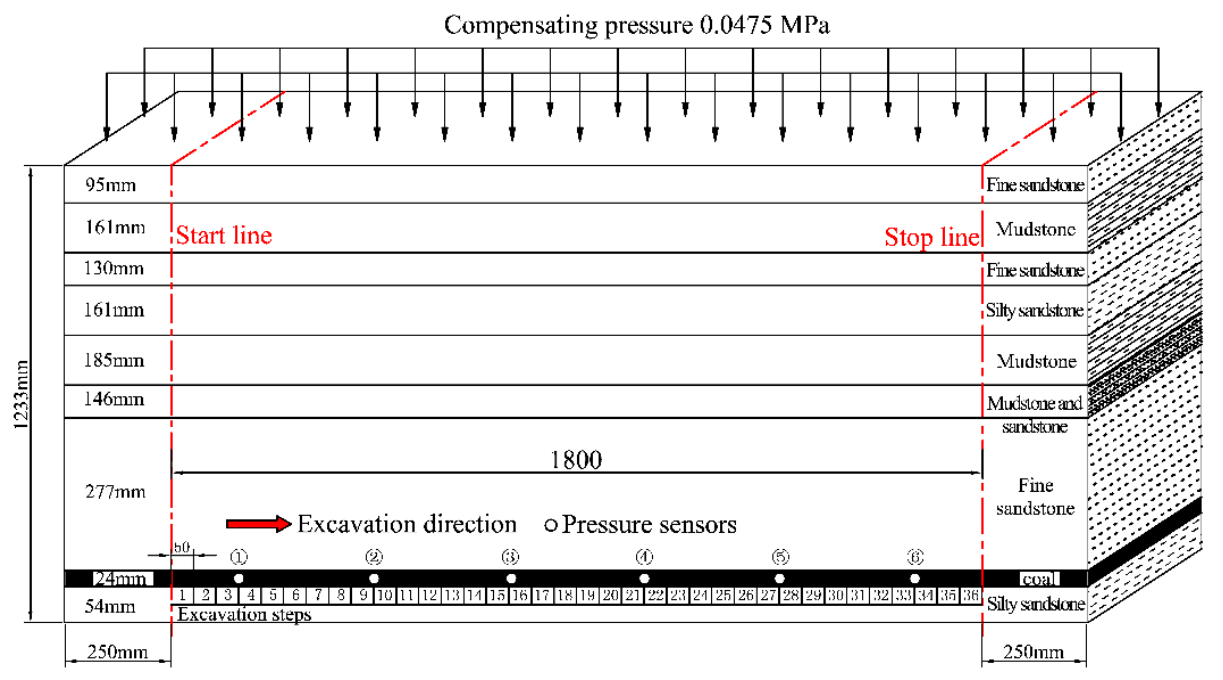

Figure 5. The model mining and backfilling sequence and the distribution of pressure sensors.

\section{Selection of Solid Backfill Analogs}

\subsection{Tests of the Deformation Behavior of the Solid Backfill Body}

A solid backfill body is subjected to confined compression after the roof in the mined-out area becomes deformed. The degree of deformation of the solid backfill body varies with the stress imposed on it by the roof. The coal gangue used by the solid backfill coal mining face in the Jining No. 3 coal mine was adopted for testing purposes. The universal material testing system and specially-made compact steel cylinder shown in Figure 6 were used to test the coal gangue's deformation behavior under confined compression [11]. 


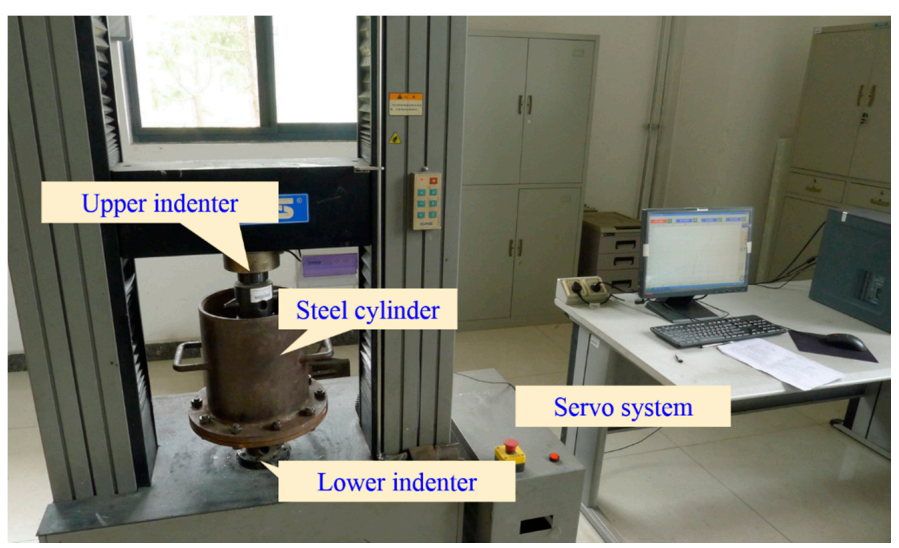

Figure 6. The universal material testing system and specially-made compact steel cylinder.

Two sets of tests were performed to simulate two backfilling states of the coal gangue: no tamping, and tamping by a force of $2 \mathrm{MPa}$. During the test involving no tamping force, stress was directly applied to the coal gangue inside the steel cylinder until it reached $16.5 \mathrm{MPa}$, which was the stress to which the primary rock in Face No. 6304 was subjected. The strain-stress curve of the coal gangue during the compaction process was recorded. During the test involving tamping force, a stress of $2 \mathrm{MPa}$ was initially applied to the coal gangue inside the steel cylinder, before being unloaded to $0 \mathrm{MPa}$. Stress was then reapplied until it reached $16.5 \mathrm{MPa}$. The strain-stress curve of the coal gangue during this process was also recorded.

\subsection{Design of Solid Backfill Analogs for Different Backfilling Scenarios}

To precisely simulate the roof deformation and stress changes of the face during solid backfill coal mining, it was necessary to design a suitable solid backfill analog that had a similar strain-stress relationship to that of the actual solid backfill body. Based on past test experiences, sponges and plain paper were used as the solid backfill analog. Tests have revealed that after the sponge is pre-compressed, its strain-stress curve is closest to that of an actual solid backfill body. The sponge was therefore pre-compressed by veneers and Scotch tape and fixed at an appropriate height, as shown in Figure 7.
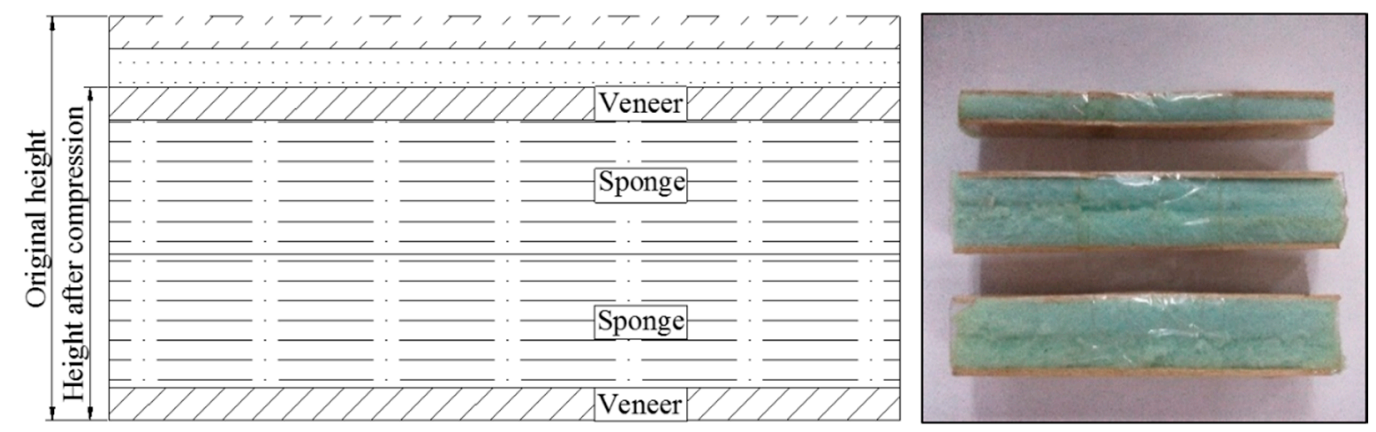

Figure 7. Diagram and field photo of the material simulating the backfill body.

In view of the backfilling heights of $1.2 \mathrm{~cm}$ and $2.4 \mathrm{~cm}$ required by the tests, different combinations of sponges and paper were designed, which resulted in 13 different variations, as shown in Table 3.

An MTS electro-hydraulic servo tester (MTS Systems Co., Eden Prairie, MN, USA) was used to perform uniaxial compression tests on each group. The strain-stress curve of each group was obtained by providing stress loading ranging from $0 \mathrm{kPa}$ to $66 \mathrm{kPa}$ (similar pressure stress to $16.5 \mathrm{MPa}$ ). Comparisons to the strain-stress curves of the coal gangue mentioned in Section 3.1 indicate that 
the strain-stress curves of groups 2, 7 and 10 were the closest. Therefore, those groups were used as solid backfill analogs for the scenarios with roof-controlled backfilling ratios of $40 \%, 82.5 \%$, and $97 \%$. Figure 8 displays the results of the strain-stress curves for comparison.

Table 3. Various combinations of sponge and paper.

\begin{tabular}{ccccc}
\hline Group & Backfill Height $(\mathbf{m m})$ & Layers of Sponge & Sponge Height after Fixed $(\mathbf{m m})$ & Paper Thickness $(\mathbf{m m})$ \\
\hline 1 & & 1 & 6 & 6 \\
2 & 12 & 2 & 12 & 0 \\
3 & 2 & 6 & 6 \\
4 & 3 & 12 & 0 \\
5 & 2 & 12 & 0 \\
\hline 6 & 2 & 12 & 12 \\
7 & 24 & 18 & 6 \\
8 & & 3 & 24 & 0 \\
9 & & 3 & 12 & 6 \\
10 & & 4 & 18 & 0 \\
11 & & 24 & 6 \\
12 & & 18 & 0 \\
13 & & 24 & \\
\hline
\end{tabular}

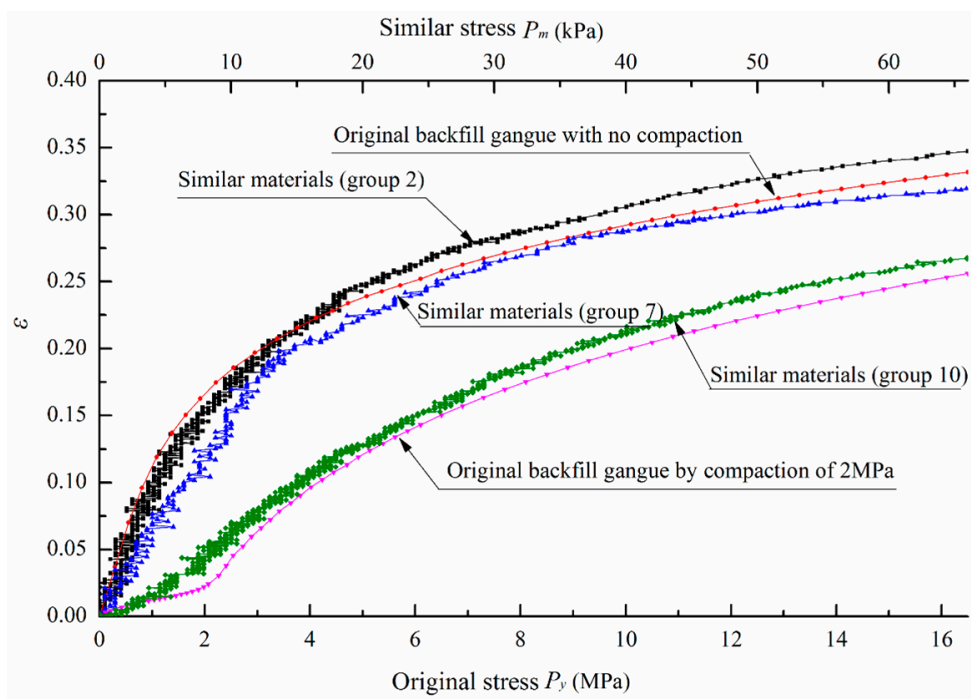

Figure 8. Comparisons of strain-stress curves between similar materials and backfilling bodies.

When performing the physical simulation experiments, the solid backfill analogs were made into cuboids measuring $300 \mathrm{~mm} \times 50 \mathrm{~mm}(\mathrm{~L} \times \mathrm{W})$. For every $50 \mathrm{~mm}$ of mining, a corresponding solid backfill analog was immediately placed inside the mined-out space, and the mining and backfilling continued like this in sequence.

\section{Deformation Behavior of the Hard Roof under Different Backfilling Scenarios}

\subsection{Scenario 1: Roof-Controlled Backfilling Ratio of 0}

When the roof-controlled backfilling ratio was 0 , i.e., the caving method was used, the hard roof displayed obvious characteristics of initial fractures and periodic fractures. In order to directly correspond to the actual face, the data in the similarity model had to be converted from the data from the actual working face using a similarity ratio. The following is a staged description of the deformation behavior for Scenario 1: 
(1) In the initial phase of mining, the roof displayed little deformation. When the mining reached a distance of $60 \mathrm{~m}$ from the start line, the maximum displacement of the roof was only $0.11 \mathrm{~m}$, and no obvious cracks were observed.

(2) When the mining reached a distance of $127.5 \mathrm{~m}$, obvious separation was observed between the hard roof and the No. 6 stratum-mudstone and sandstone interbedding; the maximum displacement in the vertical direction was $0.29 \mathrm{~m}$. At a distance of $67 \mathrm{~m}$ from the start line, a crack about $14 \mathrm{~m}$ high occurred at the lower part of the hard roof. The crack did not penetrate through the roof.

(3) When the mining reached a distance of $157.5 \mathrm{~m}$, the hard roof experienced its initial fracture. Penetrating cracks occurred above the start line, above the middle of the mined-out area, and above the working face. The roof subsided by a maximum amount of $2.91 \mathrm{~m}$. At this time, the No. 6 stratum subsided and was separated from the No. 5 stratum above, as shown in Figure 9.

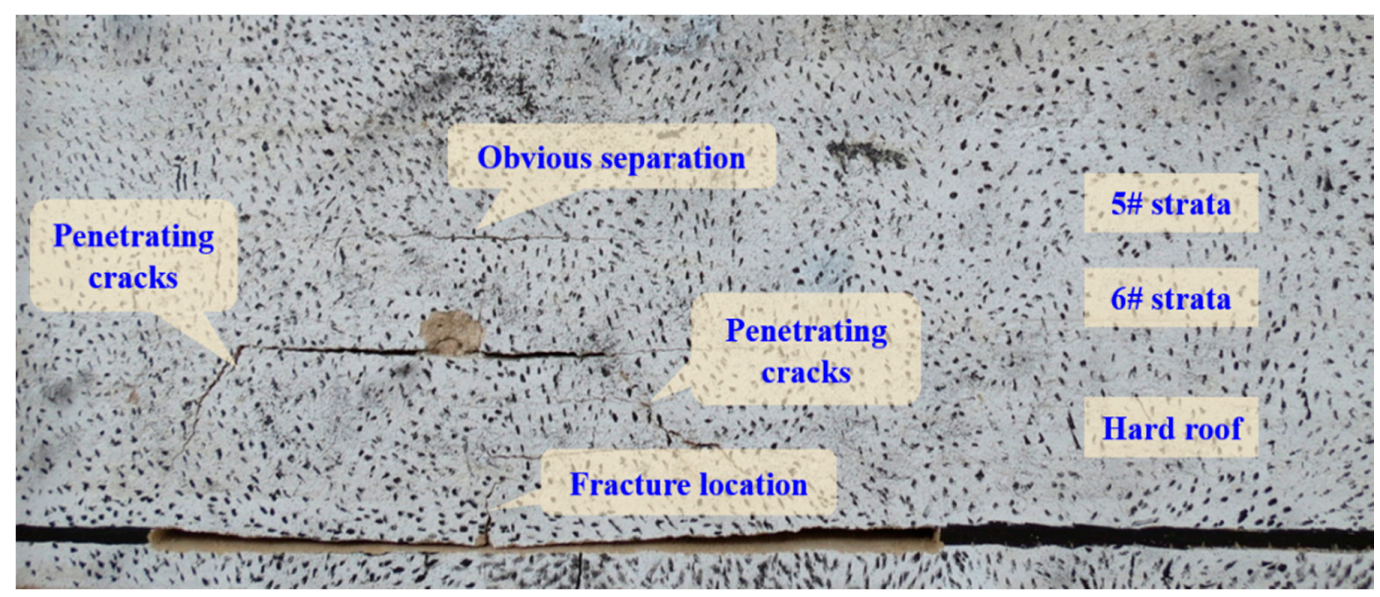

Figure 9. Deformation and displacement distribution cloud graph of overlying strata when the mining had advanced to $157.5 \mathrm{~m}$ with a roof-controlled backfilling ratio of 0 (caving method).

(4) When the mining reached a distance of $217.5 \mathrm{~m}$, the hard roof experienced a periodic fracture, with a fracture interval of $60 \mathrm{~m}$. The overlying strata were affected by the mining activities; the No. 5 stratum experienced a maximum subsidence of $2.2 \mathrm{~m}$, as shown in Figure 10.

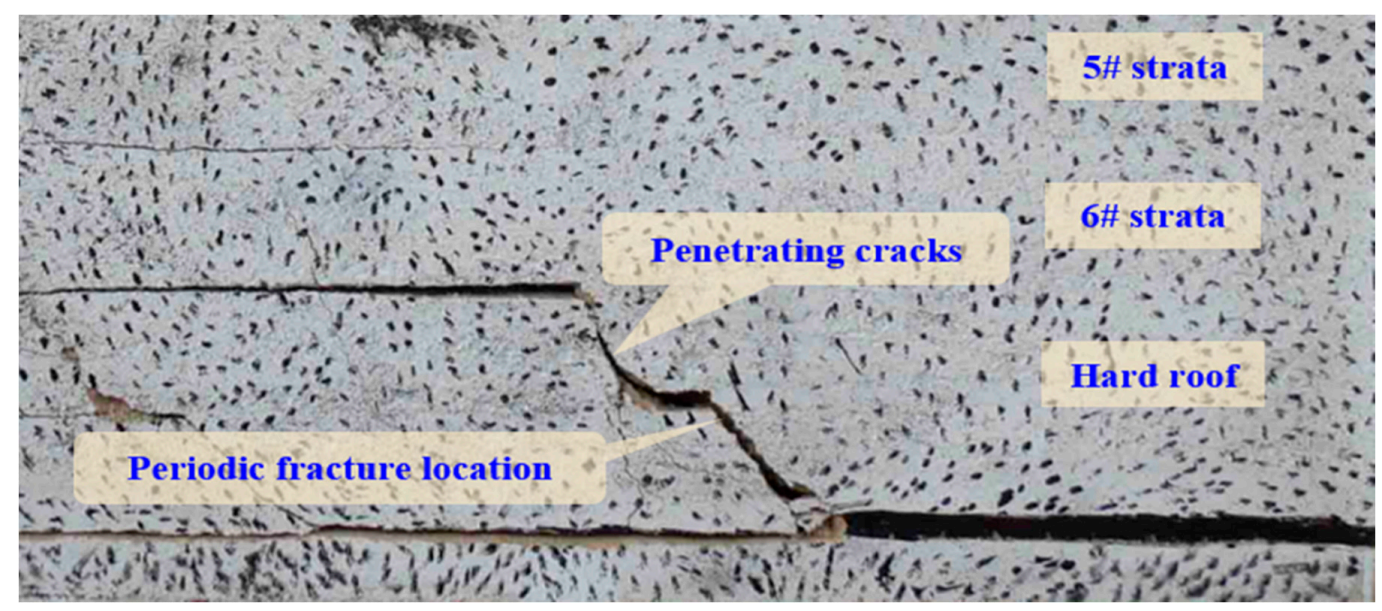

Figure 10. Deformation and displacement distribution cloud graph of overlying strata when the mining had advanced to $217.5 \mathrm{~m}$ with a roof-controlled backfilling ratio of 0 (caving method). 
(5) When the mining reached a distance of $270 \mathrm{~m}$ (the stop line), a second periodic fracture occurred in the hard roof, with a fracture interval of $52 \mathrm{~m}$. The hard roof subsided by a maximum amount of $3.42 \mathrm{~m}$, and cracks were seen developing across the whole model height, as shown in Figure 11.

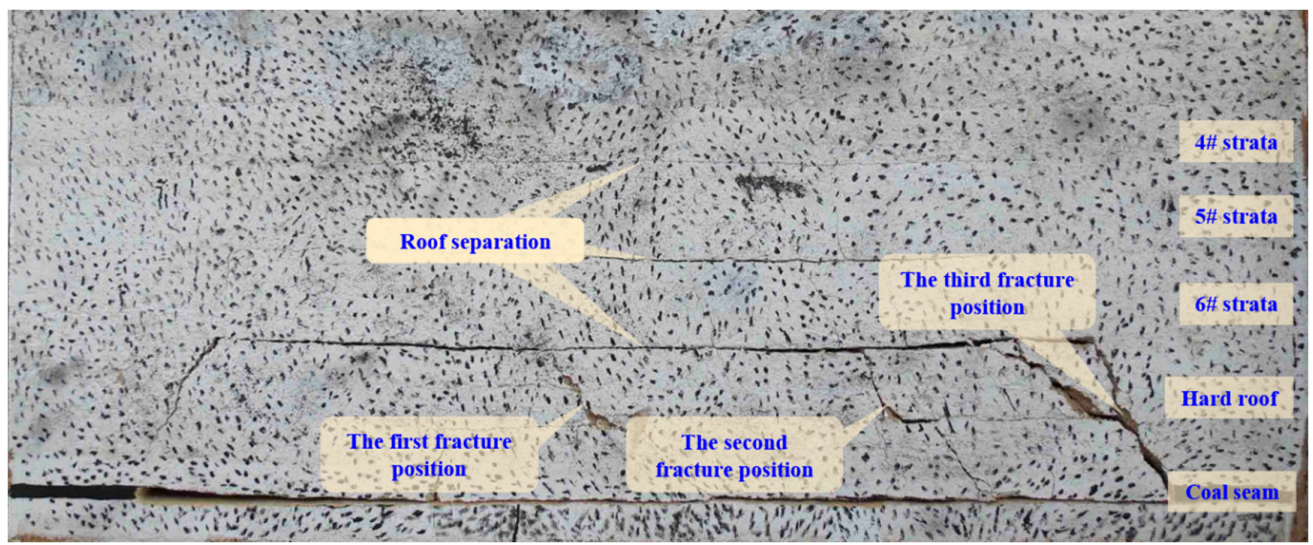

(a)

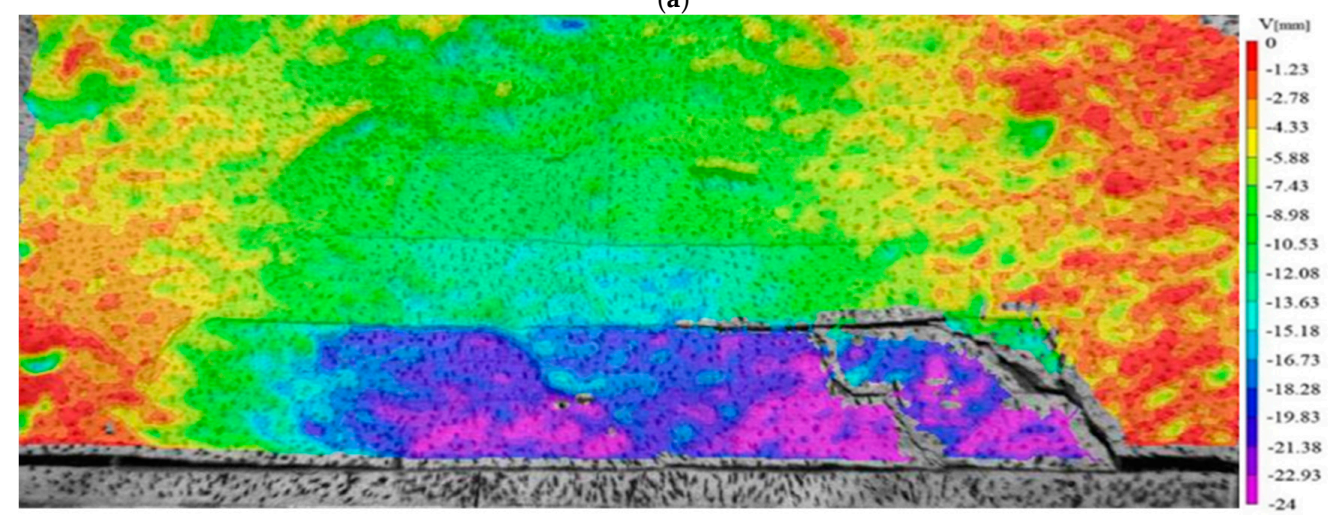

(b)

Figure 11. Deformation and displacement distribution cloud graph of overlying strata when the mining had advanced to $270 \mathrm{~m}$ with a roof-controlled backfilling ratio of 0 (caving method). (a) Deformation of overlying strata; (b) Displacement distribution cloud graph of overlying strata.

\subsection{Scenario 2: Roof-Controlled Backfilling Ratio of $40 \%$}

When the roof-controlled backfilling ratio was $40 \%$, i.e., the mining height was $3.5 \mathrm{~m}$ and the backfilling height was $1.75 \mathrm{~m}$, the hard roof still displayed obvious characteristics of initial fractures and periodic fractures. The deformation behavior can be summarized by the following five stages:

(1) Before the mining reached a distance of $135 \mathrm{~m}$, the roof displayed some degree of deformation but did not show obvious cracks or separations.

(2) When the mining reached a distance of $135 \mathrm{~m}$, at a distance of $28 \mathrm{~m}$ from the start line, a crack about $11 \mathrm{~m}$ high occurred at the lower part of the roof. The crack did not penetrate through the roof. At this time, the roof subsided by a maximum amount of $0.51 \mathrm{~m}$ and was separated from the No. 6 stratum.

(3) When the mining reached a distance of $165 \mathrm{~m}$, the hard roof experienced its initial fracture. Obvious cracks were observed above the start line, above the middle of the mined-out area, and above the working face. Due to uneven laying of the model, the fracture of the roof was somewhat stratum-wise. Above the start line and middle of the mined-out area, cracks did not penetrate through the rock mass but developed from the vertical direction toward the horizontal direction. At this time the maximum subsidence of the roof was $2.41 \mathrm{~m}$, as shown in Figure 12. 


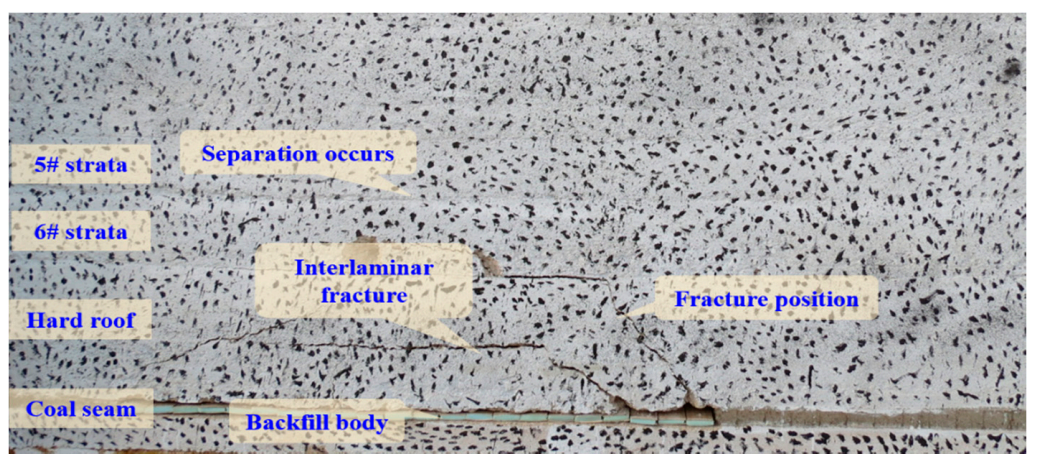

Figure 12. Deformation and displacement distribution cloud graph of overlying strata when the mining had advanced to $165 \mathrm{~m}$ with a roof-controlled backfilling ratio of $40 \%$.

(4) When the mining reached a distance of $225 \mathrm{~m}$, the hard roof experienced a periodic fracture, with a fracture interval of $60 \mathrm{~m}$. The fractured roof weighed completely on the backfill body, and penetrating cracks occurred above the working face. At this time, the separations and cracks above the middle of the mined-out area gradually closed. The No. 6 stratum displayed vertical penetrating cracks and was separated from the No. 5 stratum, which also subsided by a maximum amount of $1.5 \mathrm{~m}$, as shown in Figure 13.

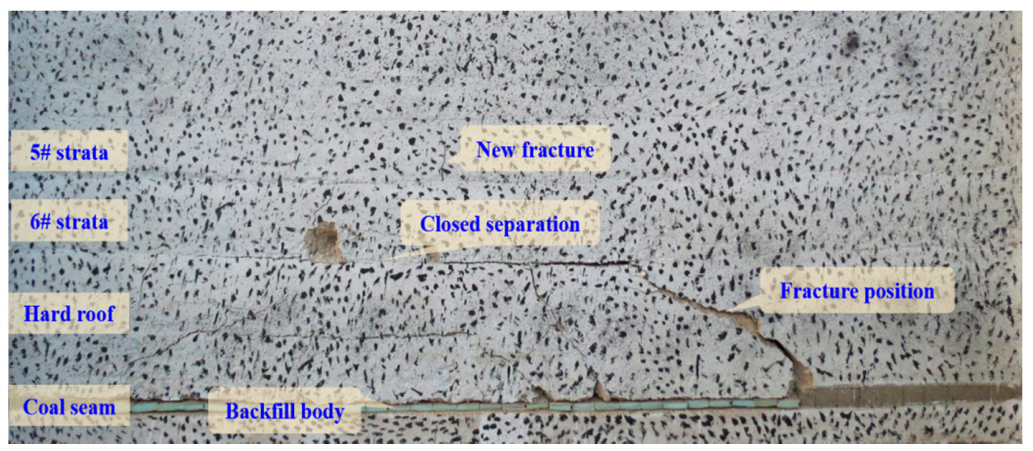

Figure 13. Deformation and displacement distribution cloud graph of overlying strata when the mining had advanced to $225 \mathrm{~m}$ with a roof-controlled backfilling ratio of $40 \%$.

(5) When the mining reached a distance of $270 \mathrm{~m}$ (the stop line), a second periodic fracture occurred in the hard roof, with a fracture interval of $45 \mathrm{~m}$. By this time cracks were developing across the entire model height, as shown in Figure 14.

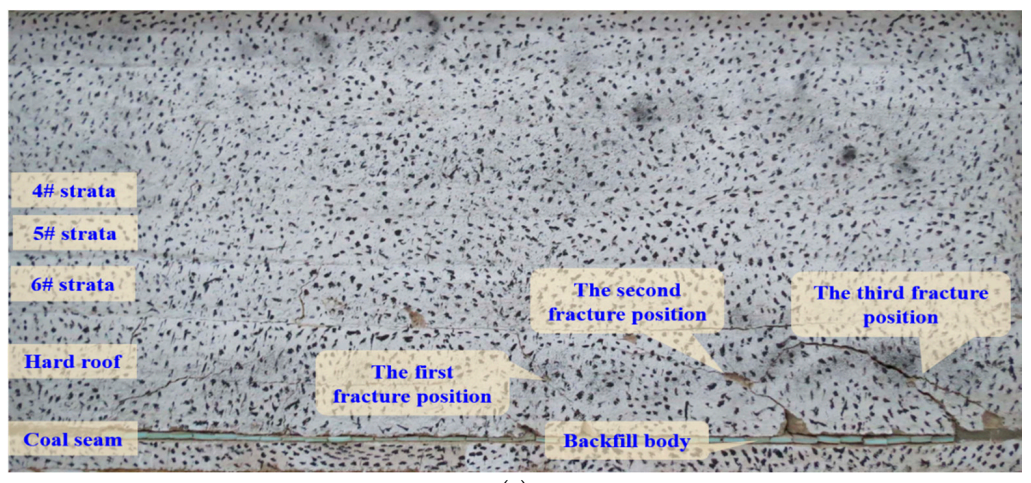

(a)

Figure 14. Cont. 


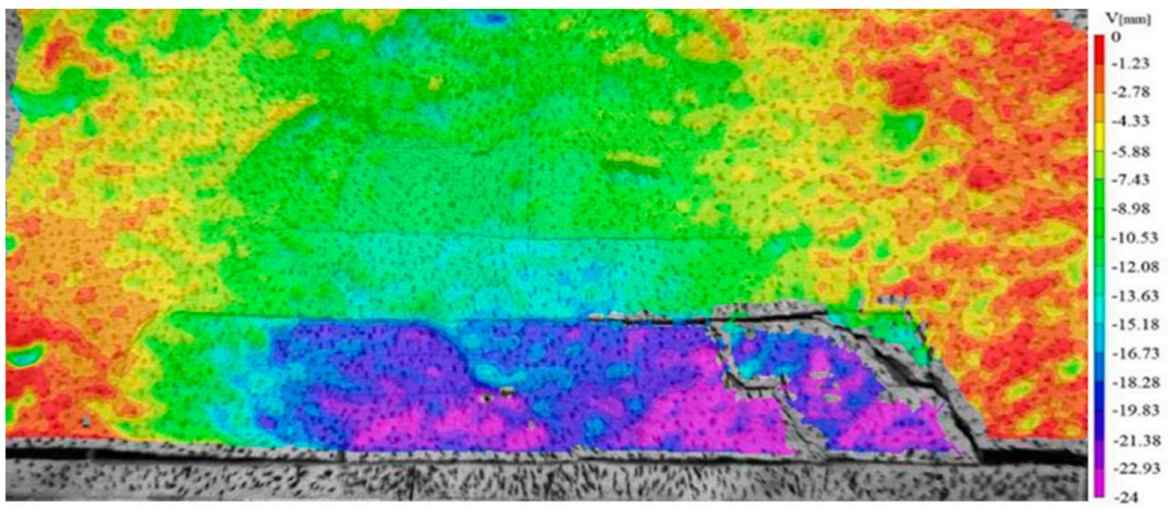

(b)

Figure 14. Deformation and displacement distribution cloud graph of overlying strata when the mining had advanced to $270 \mathrm{~m}$ with a roof-controlled backfilling ratio of $40 \%$. (a) Deformation of overlying strata; (b) Displacement distribution cloud graph of overlying strata.

\subsection{Scenario 3: Roof-Controlled Backfilling Ratio of $82.5 \%$}

When the roof-controlled backfilling ratio was $82.5 \%$, i.e., both the backfilling height and the mining height were $3.5 \mathrm{~m}$, the hard roof fractured but did not display obvious weighting phenomena. During the entire backfill mining process, the rock mass did not show any caving zones; only cracking zones and curve subsidence zones. The deformation behavior can be summarized by the following three stages:

(1) Before a distance of $150 \mathrm{~m}$, the roof displayed successional curve subsidence with mining in the face. The maximum subsidence of the roof was only $0.13 \mathrm{~m}$ at a distance of $75 \mathrm{~m}$.

(2) When the mining reached a distance of $150 \mathrm{~m}$, at a distance of $67 \mathrm{~m}$ from the start line, a crack about $13 \mathrm{~m}$ high occurred at the lower part of the roof. At this time the roof subsided by a maximum amount of $0.53 \mathrm{~m}$, as shown in Figure 15.

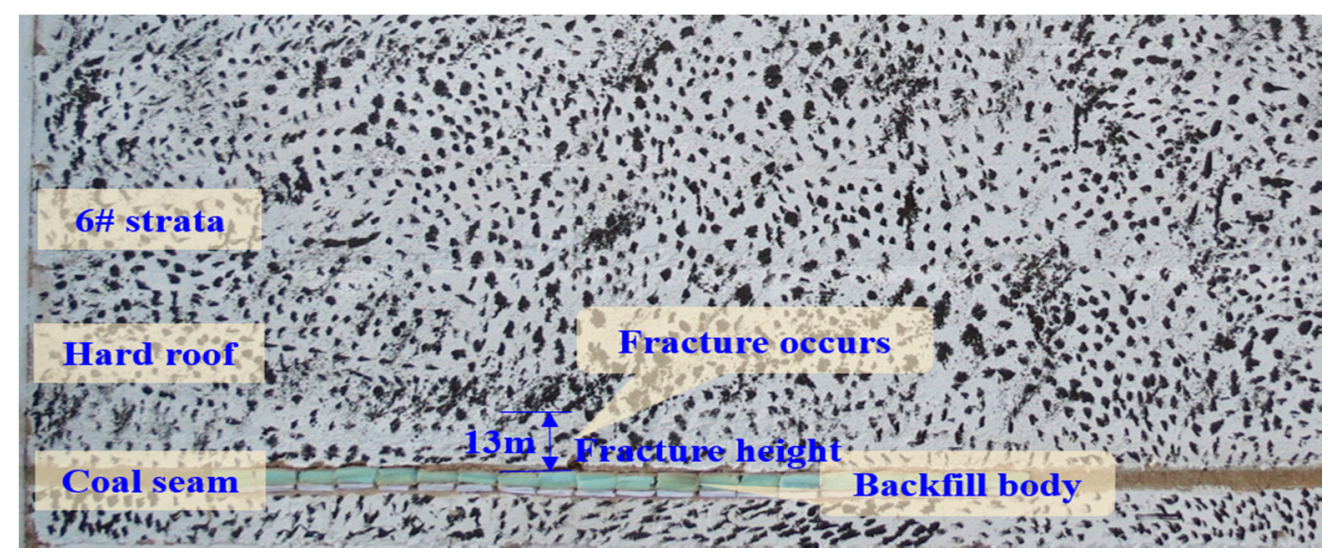

Figure 15. Deformation and displacement distribution cloud graph of overlying strata when the mining had advanced to $150 \mathrm{~m}$ with a roof-controlled backfilling ratio of $82.5 \%$.

(3) No obvious new cracks or separations occurred until the completion of mining in the working face. Once the deformation of the hard roof and the overlying strata had become stable, the existing crack developed to a height of $63 \mathrm{~m}$, with the roof subsiding by a maximum amount of $1.13 \mathrm{~m}$, as shown in Figure 16. 


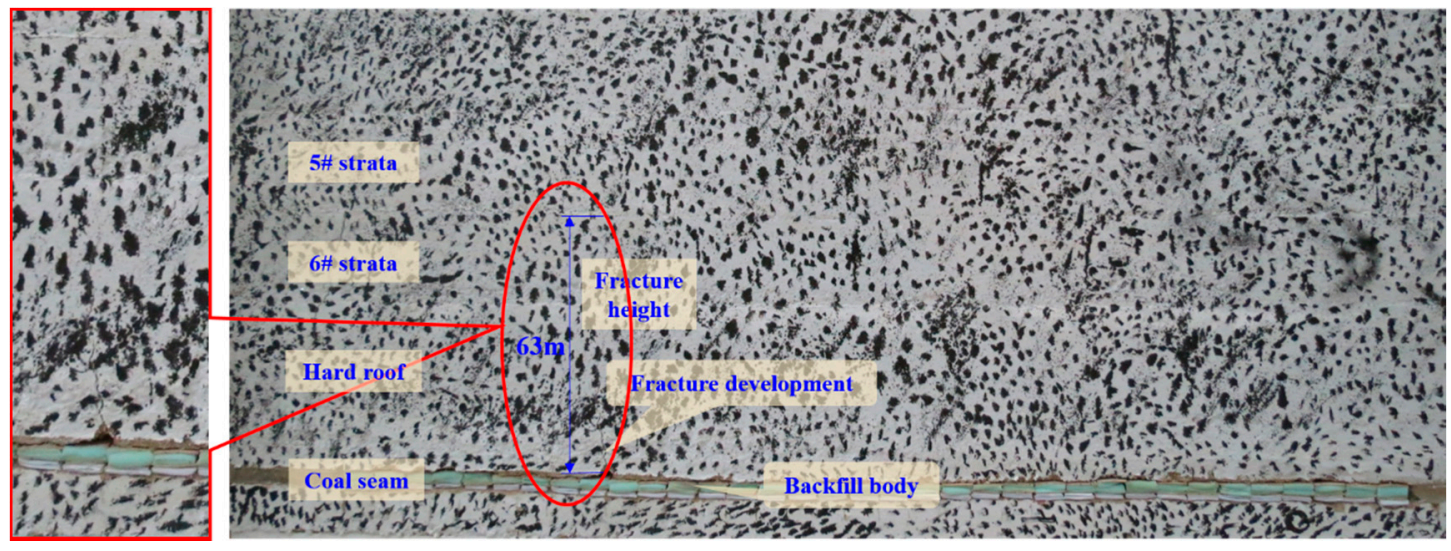

(a)

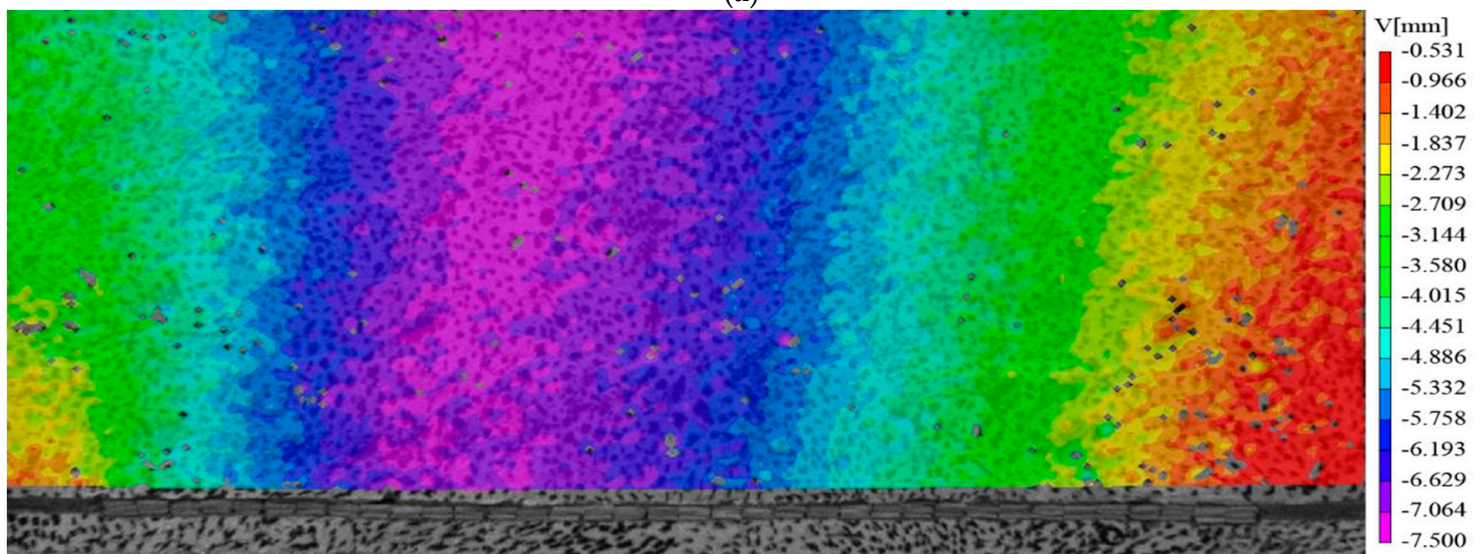

(b)

Figure 16. Deformation and displacement distribution cloud graph of overlying strata when the mining had advanced to $270 \mathrm{~m}$ with a roof-controlled backfilling ratio of $82.5 \%$. (a) Deformation of overlying strata; (b) Displacement distribution cloud graph of overlying strata.

\subsection{Scenario 4: Roof-Controlled Backfilling Ratio of 97\%}

When the roof-controlled backfilling ratio was $97 \%$, i.e., both the backfilling height and the mining height were $3.5 \mathrm{~m}$, the backfill body was compressed by an initial stress of $2 \mathrm{MPa}$. During the modeled mining process, the hard roof did not fracture and only one vertical crack developed. The overlying strata did not show any caving zones; only cracking zones and curve subsidence zones. The deformation behavior can be summarized by the following three stages:

(1) Before a distance of $232.5 \mathrm{~m}$, the roof only showed curve subsidence, with no obvious separations or cracks. The maximum subsidence of the roof was $0.43 \mathrm{~m}$ at a distance of $150 \mathrm{~m}$.

(2) When the mining reached a distance of $232.5 \mathrm{~m}$, at a distance of $125.5 \mathrm{~m}$ from the start line, a crack about $10 \mathrm{~m}$ high occurred at the lower part of the roof. The crack did not penetrate through the roof. At this time the roof subsided by a maximum amount of $0.77 \mathrm{~m}$.

(3) As the mining advanced, the crack developed higher, but no new cracks or separations developed. After the completion of mining in the working face, the existing crack grew to a maximum of $32 \mathrm{~m}$ but still did not penetrate through the roof. The maximum subsidence of the roof was $0.81 \mathrm{~m}$, as shown in Figure 17. 


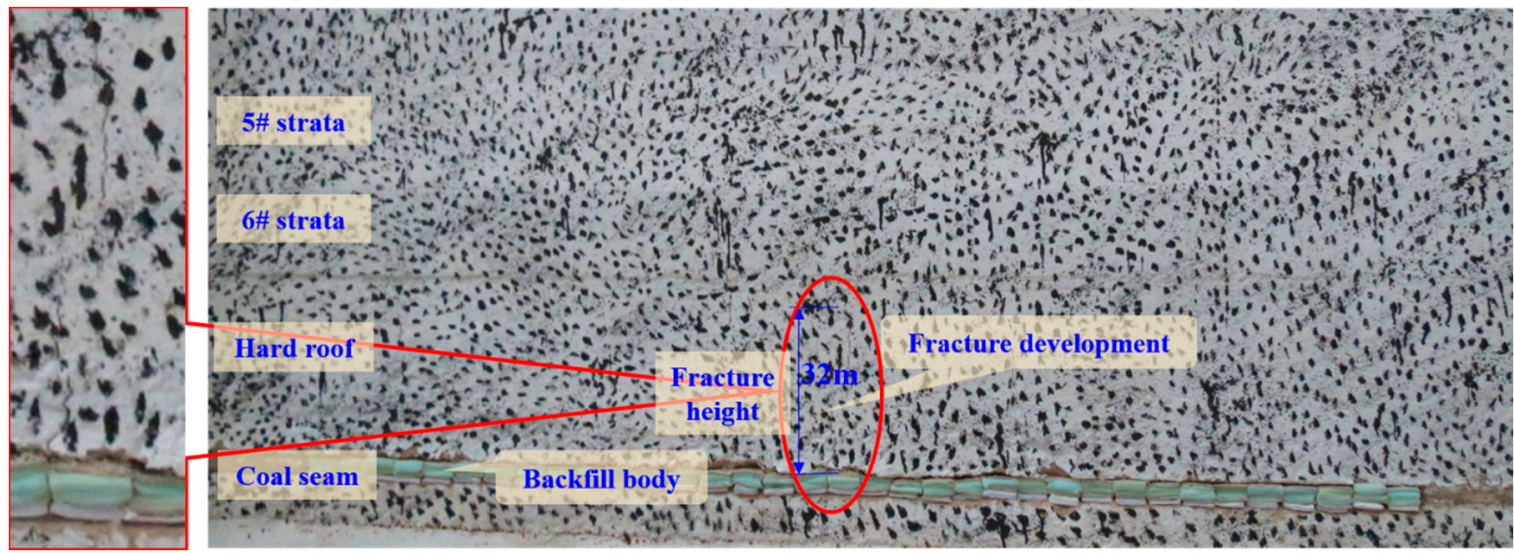

(a)

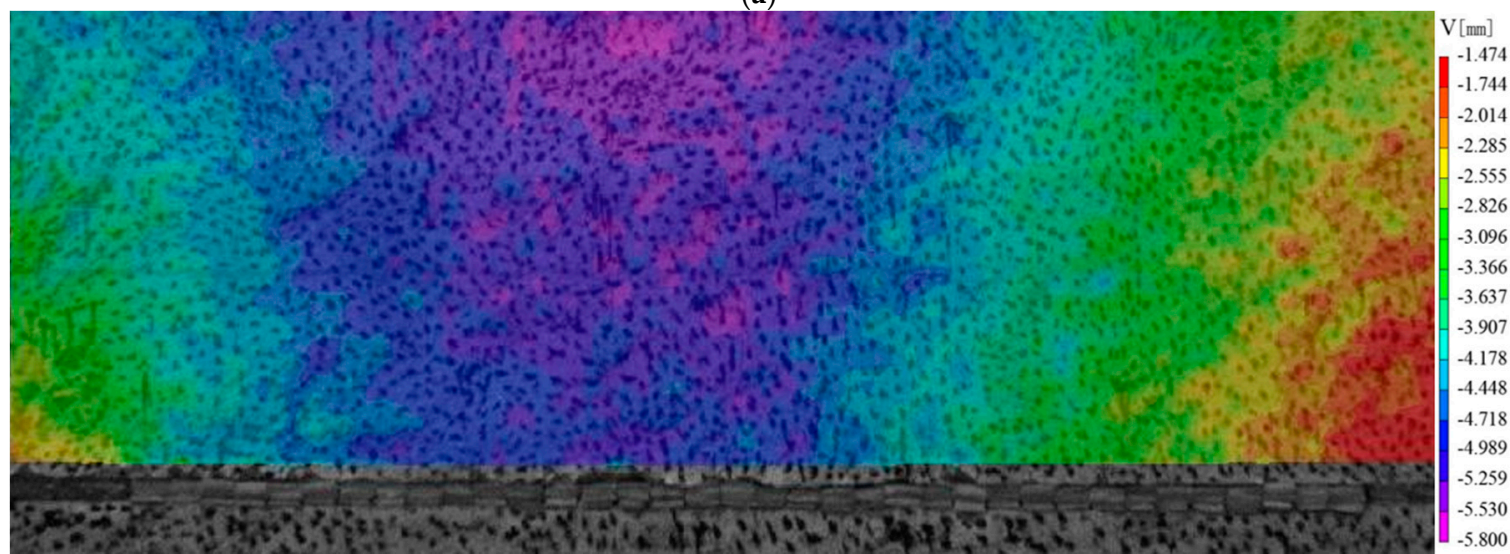

(b)

Figure 17. Deformation and displacement distribution cloud graph of overlying strata when the mining had advanced to $270 \mathrm{~m}$ with a roof-controlled backfilling ratio of $97 \%$. (a) Deformation of overlying strata; (b) Displacement distribution cloud graph of overlying strata.

\section{Analysis of the Solid Backfill Body's Performance in Controlling Deformation of the Hard Roof}

\subsection{Effect of the Solid Backfill Body on Roof Deformation}

Deformation characteristics of the hard roof were summarized, compared, and analyzed based on the four groups of experiments with different roof-controlled backfilling ratios. The results are shown in Table 4. At the bottom of the roof, 37 evenly spaced points were selected to obtain the final roof subsidence curves after the completion of mining in each scenario. These curves are displayed in Figure 18.

Table 4. Roof deformation comparison for different roof-controlled backfilling rates.

\begin{tabular}{cccccc}
\hline $\begin{array}{c}\text { Roof-Controlled } \\
\text { Backfilling Ratio }\end{array}$ & $\begin{array}{c}\text { Roof First } \\
\text { Caving Span (m) }\end{array}$ & $\begin{array}{c}\text { Roof Periodic } \\
\text { Caving Span (m) }\end{array}$ & $\begin{array}{c}\text { Mining Distance } \\
\text { When Fracture } \\
\text { First Occurs (m) }\end{array}$ & $\begin{array}{c}\text { Maximum } \\
\text { Height of } \\
\text { Fracture (m) }\end{array}$ & $\begin{array}{c}\text { Maximum Roof } \\
\text { Subsidence (m) }\end{array}$ \\
\hline $0 \%$ & 157.5 & 56 & 127.5 & Height of model & 3.42 \\
$40 \%$ & 165 & 52.5 & 135 & Height of model & 2.49 \\
$82.5 \%$ & 180 & None & 150 & 63 & 1.13 \\
$97 \%$ & None & None & 232.5 & 32 & 0.81 \\
\hline
\end{tabular}




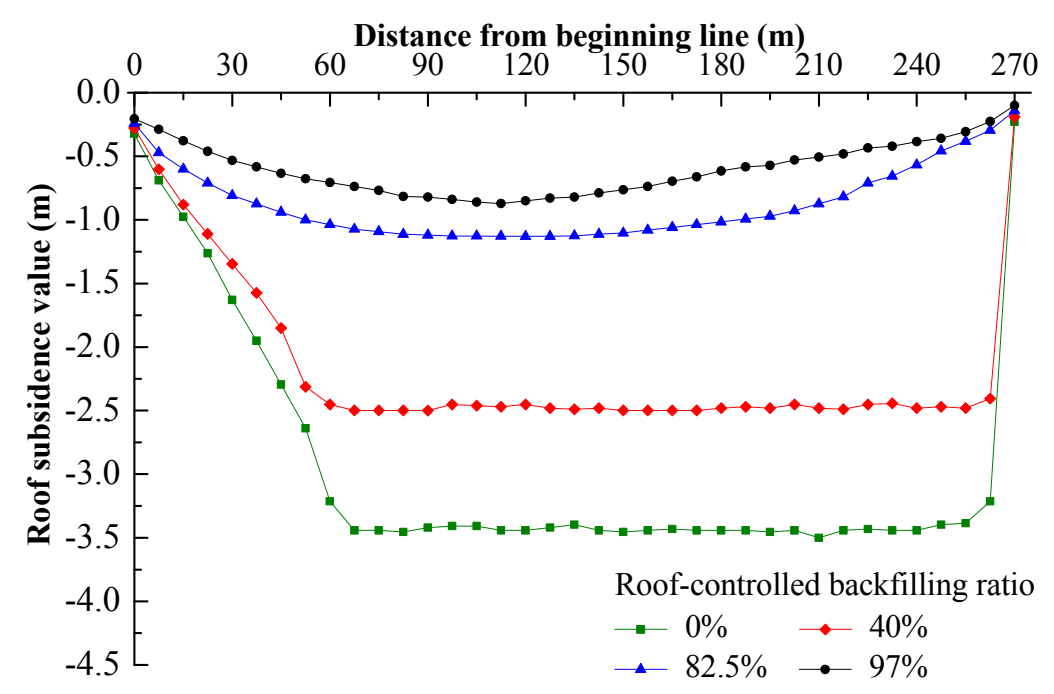

Figure 18. Stabilized subsidence curves for different roof-controlled backfilling ratios.

From Table 4 and Figure 18, the following becomes apparent:

(1) The maximum subsidence of the hard roof decreased with increasing roof-controlled backfilling ratio. When the roof-controlled backfilling ratio was $97 \%$ in comparison with the caving method $(0 \%)$, the maximum subsidence of the hard roof dropped from $3.42 \mathrm{~m}$ to $0.81 \mathrm{~m}$; a decrease of $76.3 \%$. As the roof-controlled backfilling ratio increased, the maximum height of the cracks that developed decreased; the maximum was only $32 \mathrm{~m}$ for the scenario with a backfilling ratio of $97 \%$.

(2) When the roof-controlled backfilling ratios were $0 \%$ and $40 \%$, the hard roof did not make contact with the backfill body prior to the occurrence of fractures, and displayed obvious initial and periodic fractures. Meanwhile, the mining distance between two fractures was only the distance of one cycle of mining. Due to the uneven laying of the rock strata and the error in the mining time, it was considered that the fracture intervals under these two scenarios were the same and that the mining distance at which the first roof crack appeared under both scenarios was also the same.

(3) When the roof-controlled backfilling ratios were $82.5 \%$ and $97 \%$, the hard roof maintained contact with the backfill body the entire time. As mining progressed along the working face, the roof displayed successional curve subsidence, but with no sudden fractures. Only one crack developed and the mining distance at which the crack appeared was $150 \mathrm{~m}$ and $232.5 \mathrm{~m}$ for ratios of $82.5 \%$ and $97 \%$, respectively, compared to a distance of $127.5 \mathrm{~m}$ with the caving method.

The above results indicate that, with an increase of the backfilling ratio, the solid backfill body effectively controlled the roof's deformation, and the final subsidence of the roof decreased with increasing backfilling ratio. However, the backfilling ratio needed to reach a certain level before the roof was totally impervious to fractures. The critical factor was whether the roof contacted the backfill body prior to the occurrence of the fracture. When the backfilling ratio reached $82.5 \%$ and higher, the roof no longer displayed any initial fractures or periodic fractures.

\subsection{Effect of the Solid Backfill Body on Distribution of Abutment Stress Ahead of the Face}

During mining in the four scenarios, the data from the pressure sensors in the coal seam were recorded. The stable values from each mining and backfilling cycle were used to derive distribution curves of the abutment stress ahead of the face for different backfilling ratios. The results are shown in Figure 19 and in Table 5. 


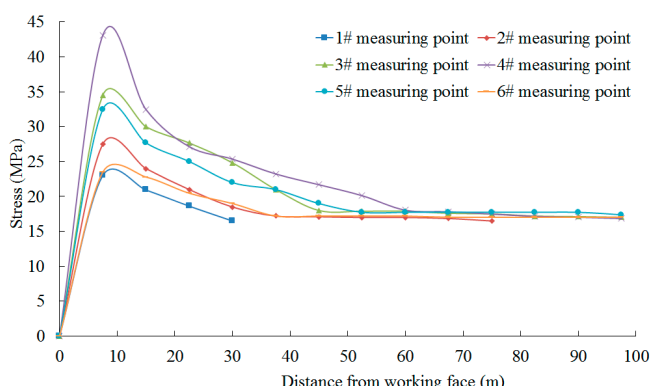

(a)

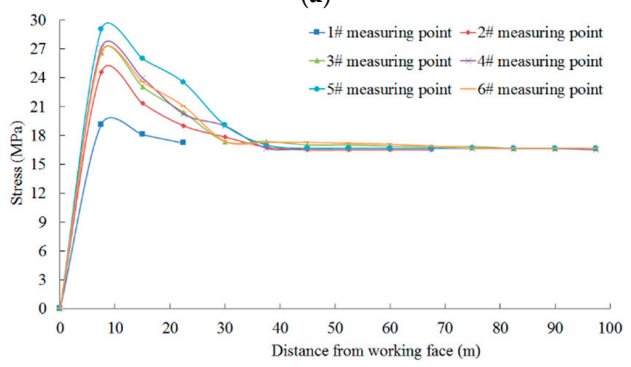

(c)

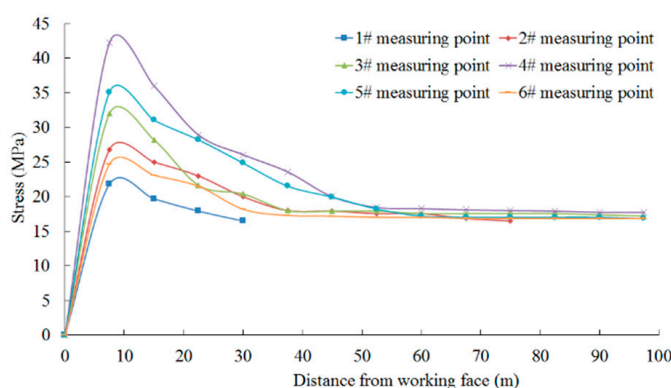

(b)

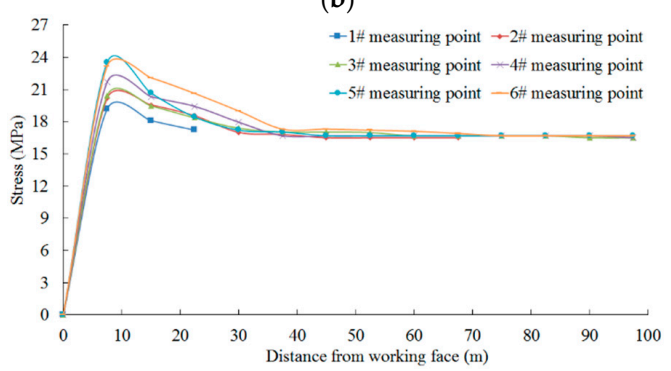

(d)

Figure 19. Distribution of abutment stress ahead of the face for different roof-controlled backfilling ratios. (a) $0 \%$; (b) $40 \%$; (c) $82.5 \%$; and (d) $97 \%$.

Table 5. Comparison of abutment stress distribution ahead of the face for different roof-controlled backfilling ratios.

\begin{tabular}{cccccc}
\hline $\begin{array}{c}\text { Roof-Controlled } \\
\text { Backfilling Ratio }\end{array}$ & $\begin{array}{c}\text { Backfill } \\
\text { Height (m) }\end{array}$ & $\begin{array}{c}\text { Roof First } \\
\text { Caving Span (m) }\end{array}$ & $\begin{array}{c}\text { Peak Value of } \\
\text { Advancing Abutment } \\
\text { Pressure (MPa) }\end{array}$ & $\begin{array}{c}\text { Maximum Stress } \\
\text { Concentration } \\
\text { Factor }\end{array}$ & $\begin{array}{c}\text { Influence Range of } \\
\text { Advancing Abutment } \\
\text { Pressure (m) }\end{array}$ \\
\hline 0 & 0 & 157.5 & 43.1 & 2.61 & 45.0 \\
$40 \%$ & 1.75 & 165 & 42.3 & 2.56 & 45.0 \\
$82.5 \%$ & 3.5 & 180 & 29.0 & 1.76 & 30.0 \\
$97 \%$ & 3.5 & None & 23.5 & 1.42 & 22.5 \\
\hline
\end{tabular}

The following observations can be derived from Figure 19 and Table 5:

(1) When the backfilling ratio was $40 \%$, the roof did not contact the backfill body prior to the occurrence of the fracture. The distribution of abutment stress ahead of the face under this scenario was basically the same as that under the caving method (backfilling ratio of $0 \%$ ). The peak abutment stress ahead of the face reached approximately $43 \mathrm{MPa}$, with an impact range of about $45 \mathrm{~m}$.

(2) When the backfilling ratio reached $82.5 \%$ and $97 \%$, the abutment stress ahead of the face decreased to $29 \mathrm{MPa}$ and $23.5 \mathrm{MPa}$, respectively; a decrease of $32.7 \%$ and $45.5 \%$, respectively, when compared to the caving method. The impact range also dropped significantly, reducing from $45 \mathrm{~m}$ to $30 \mathrm{~m}$ and $22.5 \mathrm{~m}$ with the backfilling ratios of $82.5 \%$ and $97 \%$, respectively.

\section{Analysis of Field Measurements}

\subsection{Mining and Geological Conditions of the Test Site}

The test site is located to the north of the main and auxiliary shafts. It was $250 \mathrm{~m}$ wide by $2200 \mathrm{~m}$ long and three panels were planned in the pilot area. The first panel, No. 6304-1, was designed to be $80 \mathrm{~m}$ wide by $548 \mathrm{~m}$ long, with a recoverable reserve of 230,000 tons; the average panel depth was about $660 \mathrm{~m}$. The uniaxial compressive strength of No. 3 coal is $11.2 \mathrm{MPa}$, and its density is $1.36 \mathrm{t} / \mathrm{m}^{3}$. The height of the coal seam is about $3.5 \mathrm{~m}$ [11]. The geological features of the roof and floor are shown in Table 6. 
Table 6. No. 3 coal seam roof and floor.

\begin{tabular}{cccl}
\hline Mine Area & Rock Category & Thickness/m & \multicolumn{1}{c}{ Rock Features } \\
\hline Main roof & $\begin{array}{c}\text { Fine- and medium- } \\
\text { grained sandstone }\end{array}$ & 41.63 & $\begin{array}{l}\text { Gray-white, largely quartz, followed by } \\
\text { feldspar and a small amount of dark and } \\
\text { green minerals, } \mathrm{f}=8-10\end{array}$ \\
\hline Immediate roof & Mudstone & $0.0-1.02$ & $\begin{array}{l}\text { Brown-gray, containing many plant root fossils, } \\
\mathrm{f}=2-3\end{array}$ \\
\hline Immediate floor & Aluminous mudstone & $0.0-3.20$ & $\begin{array}{l}\text { Light gray, smooth, containing plant } \\
\text { fossil fragments, } \mathrm{f}=2-3\end{array}$ \\
\hline Main floor & Fine-grained sandstone & 5.85 & Light gray-dark gray, dense and hard, $\mathrm{f}=6-8$ \\
\hline
\end{tabular}

\subsection{Measurement of the Ratio of Backfilled Mass to Mined Mass}

In order to monitor the backfilling quality of the panel, the mass of backfilled waste rock and mined coal is monitored every day. The backfilled-to-mined coal mass ratio is used to evaluate the backfilling effect. The mass ratio of backfilled to mined coal $\tau$ is related to the roof-controlled backfilling ratio $\varphi_{k}$ by:

$$
\tau=\varphi_{k} C_{g} / C_{c}
$$

where $C_{g}=16.46 \mathrm{kN} / \mathrm{m}^{3}$ is the bulk density of the backfilled body obtained under a pressure of $2.27 \mathrm{MPa}$ and $C_{c}=13.33 \mathrm{kN} / \mathrm{m}^{3}$ is the bulk density of the coal.

Based on monitoring data of the amount of backfilled waste rock and coal mined during the period from 15 March 2011 to 15 September 2011, the mass ratio of backfilled to mined coal of Panel No. 6304-1 is shown in Figure 19.

Figure 20 shows that the mass ratio was mostly greater than the design value of 0.93 , with an average of 1.19. Through back-calculation, the average roof-controlled backfilling ratio $\varphi_{k}$ was actually $96.4 \%$. This result is close to the fourth scheme (97\%) in the physical similarity simulation [11].

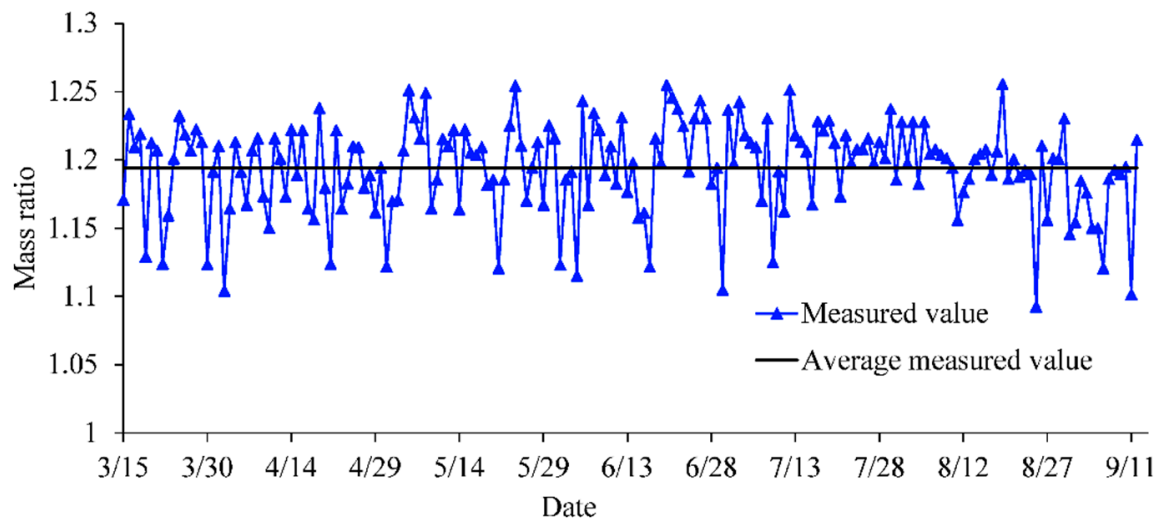

Figure 20. Variation of the mass ratio of backfilled waste to mined coal.

\subsection{Measurement of Roof Subsidence}

During mining, a roof deformation monitoring device was installed at the rear end of the shield support. It was connected via cables to a data acquisition instrument near the take-off location of the panel, so that changes in roof subsidence were monitored in real time. Three monitoring stations were deployed at the locations of 10, 30 and $60 \mathrm{~m}$ from the cutting hole. Each station had five monitoring devices uniformly distributed in the backfilling area. Taking the measurements at the $60 \mathrm{~m}$ location for instance, the largest roof subsidence was obtained, as shown in Figure 21 [11]. 


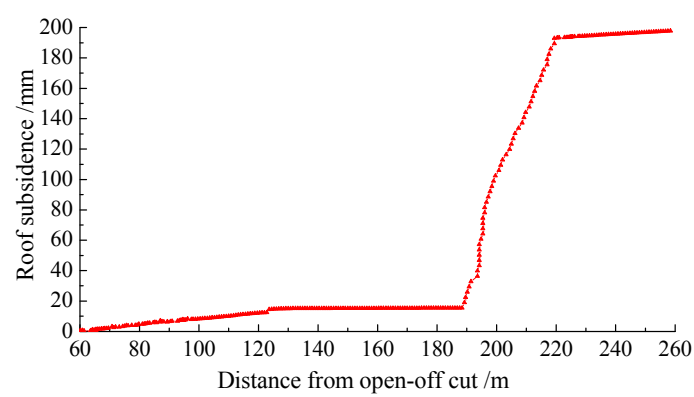

Figure 21. Measured roof subsidence in the backfilling area.

It can be known that the maximum subsidence of hard roof is $197.8 \mathrm{~mm}$, and the roof subsidence is only $5.7 \%$ of the mining height $(3.5 \mathrm{~m})$. If the hard roof is broken, the subsidence value should be much more than this measured value. It can be concluded that the roof has not been broken at the position of the $60 \mathrm{~m}$ distance from the open-off cut because of the supporting function of the backfill body. As a result, the physical similarity simulations are verified.

\subsection{Measurement of Advanced Abutment Pressure}

Three monitoring stations were deployed in both the maingate and tailgate of Panel No. 6304-1. At each monitoring point, four different drill hole depths (i.e., $3 \mathrm{~m}, 5 \mathrm{~m}, 10 \mathrm{~m}$, and $15 \mathrm{~m}$ ) were designed with a total of 24 borehole stress meters in total. Taking the measurements of the station $120 \mathrm{~m}$ from the setup room as an example, the front abutment pressure in the coal block at different depths is shown in Figure 22 [11].

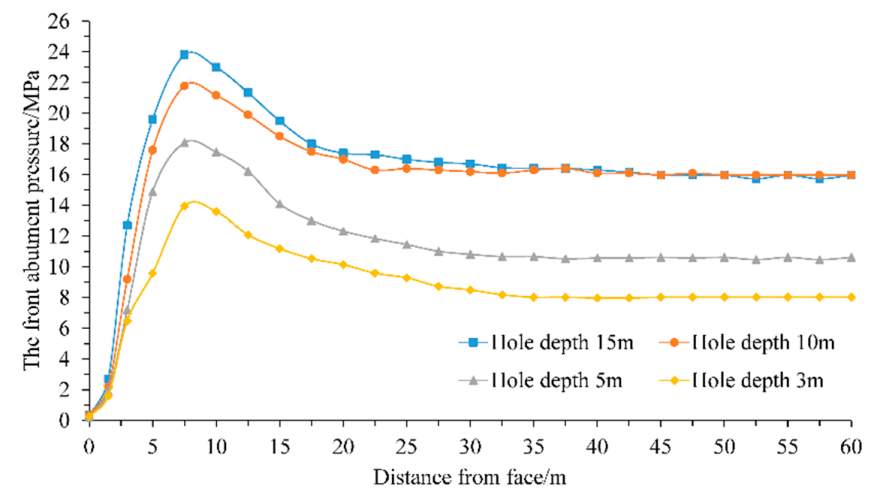

Figure 22. Measured abutment pressures at the $120 \mathrm{~m}$ station.

Figure 22 shows that the backfilled body restricted the deformation of the hard roof, mitigating the effects of mining. The stress concentration factor of the front abutment pressure was 1.44 and the influence distance was about $28 \mathrm{~m}$. This result is close to the fourth scheme (97\%) in the physical similarity simulation.

\section{Conclusions}

The following conclusions can be drawn from this study:

(1) By using similarity theory and test results of the mechanical properties of backfill materials, physical simulation experiments were performed for four scenarios of varying roof-controlled backfilling ratios $(0 \%, 40 \%, 82.5 \%$ and $97 \%)$ to study the deformation behavior of the hard roof. A combination of pre-compressed sponges and paper was used as a backfill body analogue, which precisely simulated the deformation process that the backfill body experienced under the stress of the roof for each backfilling scenario. 
(2) The solid backfill body proved to be able to support the roof. With increasing roof-controlled backfilling ratio, the maximum subsidence of the roof and the maximum height of the developing cracks decreased. When the backfilling ratio reached $97 \%$, the maximum subsidence of the hard roof was only $0.81 \mathrm{~m}$; a decrease of $76.2 \%$ compared to that of the caving method, and the maximum height of the crack in relation to the coal seam was only $32 \mathrm{~m}$.

(3) When the backfilling ratio was $40 \%$, the roof did not contact with the backfill body prior to the occurrence of the fracture. The backfill reduced the subsidence of the roof after the occurrence of the fracture, but the fracture interval and the abutment stress ahead of the face of the roof were almost the same as those seen with the caving method.

(4) When the backfilling ratio reached $82.5 \%$ and $97 \%$, the roof contacted fully with the backfill body prior to the occurrence of the fracture, and both the peak and the impact range of the abutment stress ahead of the face decreased. When the backfilling ratio reached $97 \%$, the roof no longer fractured, the concentration coefficient of the abutment stress ahead of the face was only 1.42, and the impact range decreased to $22.5 \mathrm{~m}$.

(5) After adopting the solid backfilling mining method in Panel No. 6304-1 of the Jisan Coal Mine, the average value of the roof-controlled backfilling ratio $\varphi_{k}$ reached $96.4 \%$, and it is close to the fourth scheme (97\%) in the physical similarity simulation.

Acknowledgments: The authors are grateful to the Fundamental Research Funds for the Central Universities (2017QNA22) for their support of this project.

Author Contributions: Nan Zhou, Hao Yan, and Meng Li contributed to building the experimental models for the physical simulation and analyzed the data, and Nan Zhou contributed to drafting the manuscript. Jixiong Zhang reviewed the final paper and made important suggestions and recommendations for paper revision.

Conflicts of Interest: The authors declare no conflict of interest.

\section{References}

1. Lin, C.; Deng, J.P.; Liu, Y.R.; Yang, Q.; Duan, H.F. Experiment simulation of hydraulic fracture in colliery hard roof control. J. Petrol. Sci. Eng. 2015, 138, 265-271.

2. Zheng, Z.T.; Xu, Y.; Li, D.S.; Dong, J.H. Numerical analysis and experimental study of hard roofs in fully mechanized mining faces under sleeve fracturing. Minerals 2015, 5, 758-777. [CrossRef]

3. Zhou, N.; Han, X.L.; Zhang, J.X.; Li, M. Compressive deformation and energy dissipation of crushed coal gangue. Powder Technol. 2016, 297, 220-228. [CrossRef]

4. Fredericks, P.M.; Warbrooke, P.; Wilson, M.A. A study of the effect of igneous intrusions on the structure of an Australian high volatile bituminous coal. Org. Geochem. 1985, 8, 329-340. [CrossRef]

5. Lu, C.P.; Liu, G.J.; Liu, Y.; Zhang, N.; Xue, J.H.; Zhang, L. Microseismic multi-parameter characteristics of rockburst hazard induced by hard roof fall and high stress concentration. Int. J. Rock Mech. Min. 2015, 76, 18-32. [CrossRef]

6. Li, N.; Wang, E.Y.; Ge, M.C.; Liu, J. The fracture mechanism and acoustic emission analysis of hard roof: A physical modeling study. Arab. J. Geosci. 2015, 8, 1895-1902. [CrossRef]

7. Wang, L.; Cheng, Y.P.; Xu, C.; An, F.H.; Jin, K.; Zhang, X.L. The controlling effect of thick-hard igneous rock on pressure relief gas drainage and dynamic disasters in outburst coal seams. Nat. Hazards 2013, 66, 1221-1241. [CrossRef]

8. Hirata, A.; Kameoka, Y.; Hirano, T. Safety management based on detection of possible rock bursts by AE monitoring during tunnel excavation. Rock Mech. Rock Eng. 2007, 40, 563-576. [CrossRef]

9. Zubelewicz, A.; Mróz, Z. Numerical simulation of rock burst processes treated as problems of dynamic instability. Rock Mech. Rock Eng. 1983, 16, 253-274. [CrossRef]

10. Wang, Q.X.; Wang, H.; Qi, Z.Q. An application of nonlinear fuzzy analytic hierarchy process in safety evaluation of coal mine. Saf. Sci. 2016, 86, 78-87. [CrossRef]

11. Zhang, J.X.; Li, B.Y.; Zhou, N.; Zhang, Q. Application of solid backfilling to reduce hard-roof caving and longwall coal face burst potential. Int. J. Rock Mech. Min. 2016, 88, 197-205. [CrossRef] 
12. Zhang, Q.; Zhang, J.X.; Huang, Y.L.; Ju, F. Backfilling technology and strata behaviors in fully mechanized coal mining working face. Int. J. Min. Sci. Technol. 2012, 22, 151-157. [CrossRef]

13. Zhou, N.; Zhang, J.X.; An, B.F.; Zhang, Q.; Huang, Y.L.; Ju, F. Solid material motion law in vertical feeding system within fully mechanized coal mining and backfilling technology. Environ. Eng. Manag. J. 2014, 13, 191-196.

14. Huang, Y.L.; Zhang, J.X.; An, B.F.; Zhang, Q. Overlying strata movement law in fully mechanized coal mining and backfilling longwall face by similar physical simulation. J. Min. Sci. 2011, 47, 618-627.

15. Sun, W.; Wu, A.X.; Hou, K.P.; Yang, Y.; Liu, L.; Wen, Y.M. Real-time observation of meso-fracture process in backfill body during mine subsidence using $\mathrm{X}$-ray $\mathrm{CT}$ under uniaxial compressive conditions. Constr. Build. Mater. 2016, 113, 153-162. [CrossRef]

16. Wu, D.; Sun, G.H.; Liu, Y.C. Modeling the thermo-hydro-chemical behavior of cemented coal gangue-fly ash backfill. Constr. Build. Mater. 2016, 111, 522-528. [CrossRef]

17. Zhang, J.X.; Zhou, N.; Huang, Y.L.; Zhang, Q. Impact law of the bulk ratio of backfilling body to overlying strata movement in fully mechanized backfilling mining. J. Min. Sci. 2011, 47, 73-84. [CrossRef]

18. Zhou, N. Mechanism of Preventing Dynamic Hazards under Hard Roof by Solid Backfilling Technology. Ph.D. Thesis, China University of Mining and Technology, Xuzhou, China, 2014.

19. Mohamed, M.A.H.; Christophe, D.; Farimeh, M. Improving short- and long-term stability of underground gypsum mine using partial and total backfill. Rock Mech. Rock Eng. 2010, 43, 447-461.

20. Wu, D.; Cai, S.J.; Liu, Y.C. Effects of binder on suction in cemented gangue backfill. Mag. Concr. Res. 2016, 68, 593-603. [CrossRef]

21. Zhang, Q.; Zhang, J.X.; Tai, Y.; Fang, K.; Yin, W. Horizontal roof gap of backfill hydraulic support. J. Cent. South Univ. 2010, 22, 3544-3555. [CrossRef]

22. Zhang, Q.; Zhang, J.X.; Wu, X.G.; Huang, Y.L.; Zhou, N. Roof gap rationality research of backfilling-coal mining hydraulic support. J. China Coal Soc. 2013, 38, 1325-1330.

23. Zhou, Y.J.; Chen, Y.; Zhang, J.X. Control principle and technology of final compression ratio of backfilling materials. J. Min. Saf. Eng. 2012, 29, 351-356.

24. Huang, Y.L.; Zhang, J.X.; Zhang, Q.; Nie, S.J.; An, B.F. Strata movement control due to bulk factor of backfilling body in fully mechanized backfilling mining face. J. Min. Saf. Eng. 2012, 29, 162-167.

(C) 2017 by the authors. Licensee MDPI, Basel, Switzerland. This article is an open access article distributed under the terms and conditions of the Creative Commons Attribution (CC BY) license (http:/ / creativecommons.org/licenses/by/4.0/). 